http://kitaibelia.unideb.hu/

ISSN 2064-4507 (Online) • ISSN 1219-9672 (Print)

(C) 2017, Department of Botany, University of Debrecen, Hungary

22 (1): 60-63.; 2017

DOI: $10.17542 /$ kit.22.60

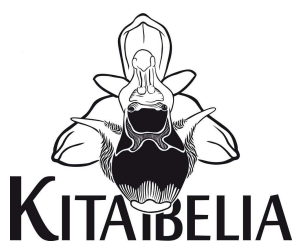

\title{
A csermelyciprus (Myricaria germanica) új hazai előfordulása
}

\author{
SÜVEGES Kristóf ${ }^{1 *}$, MolnÁR V. Attila ${ }^{1}$ \& Koscsó János ${ }^{2}$
}

(1) Debreceni Egyetem TTK Növénytani Tanszék, H-4032, Debrecen, Egyetem tér 1.; *eska1994@gmail.com (2) H-3529 Miskolc, Sályi István u. 16.

\begin{abstract}
New occurrence of Myricaria germanica in a Hungarian gravel pit
Abstract - This paper reports the second Hungarian synanthropic occurrence of the rare Myricaria germanica. One flowering individual was found in a gravel pit near Hejőpapi (NE Hungary). The closest known population of the species is $60 \mathrm{~km}$ far from newly found locality. This occurrence indicates effectivness of anemochory. It seems, that abandoned gravel pits may be potential habitats of this threataned shub species.
\end{abstract}

Keywords: anemochory, apophyte, long distance seed dispersal, Red List species, synanthropic habitat

Összefoglalás - A közlemény a Magyarországon igen ritka Myricaria germanica második olyan előfordulásáról számol be, amely ember által létrehozott termőhelyről ismert. A faj Hejőpapi mellől (SajóHernád-sík), egy kavicsbányából került elő. A faj legközelebbi lelőhelye mintegy 60 kilométerre található, így az előfordulás a szél általi terjedés (anemochoria) hatékonyságát jelzi. Úgy tűnik a kavicsbányák megfelelő termőhelyet jelenthetnek e hazánkban veszélyeztetett cserjefajnak.

Kulcsszavak: anemochoria, apofiton, kavicsbánya, másodlagos termőhely, Sajó-Hernád-sík, Tamariskafélék, veszélyeztetett faj, védett faj

\section{Bevezetés}

A csermelyciprus (Myricaria germanica (L.) Desf.) eurázsiai elterjedésű (KoRDA 2010), hazánkban kipusztulás által veszélyeztetett (KIRÁLY 2007) cserjefaj. Magyarországon védett növény, a természetvédelmi értéke 10000 Ft. Jellegzetes élőhelyei a gyorsabb folyású, durva hordalékot szállító folyók és patakok kavicsos zátonyai és fövenyei, elsősorban a montán és szubalpin régiókban (MoLNÁR V. 2003: 110.). Emiatt Magyarországon korábban sem volt gyakori, a Dráva, a Mura, a Rába és a Duna mentén (a Szigetközben) voltak ismert állományai (részletesen lásd KORDA 2010: 143-144.), amelyek egyetlen kicsiny Dráva menti populáció (FENYŐSI \& HORVÁTH 1995) kivételével, a 20. század folyamán eltűntek. Bizonytalan, megerősítetlen adatai vannak Tuzsér mellől és a „Bakony nyugati részé”-ről (vö: KoRDA 2010: 143144.).

A csermelyciprus felbukkanása másodlagos termőhelyeken nem példa nélkül való (vö. REHKLAU 2003, CSIKY in KORDA 2010: 146.), mégis sokkal ritkább esemény, mint a hasonló élőhelyigényű (elsődlegesen folyók és patakok kavicszátonyain, fövenyein előforduló) és terjedési stratégiájú (anemochor), szintén védett vízparti deréce (Chamaenerion dodonaei (Vill.) Holub, syn.: Epilobium dodonaei Vill.) megjelenése. Utóbbi faj megtelepedésére kavics-, kő-, bauxit- és szénbányákban számos példa van hazánkban (GoMBOCZ 1906, BoRos 1954, 
NÉMETh 1979, Matus 1993, MatuS \& BARINA 1998, Kun 1998, KirÁlY \& KirÁLY 1998, KovÁCS 1999, MolnÁR V. et al. 2000, ILlYÉs \& TóTH 2006, BARINA 2008, VoJTKó 2008, MÉSZÁRos \& SiMON 2009, VIRÓK et al. 2011) és külföldön (STÖCKLIN 1992, STÖCKLIN \& FAVRE 1994, RANĐELOVIĆ et al. 2016) egyaránt. A Myricaria germanica esetében viszont Magyarországon eddig egyetlen ilyen esetről volt tudomásunk: 2001-ben Virók Viktor találta Rudabányán, az egykori vasércbánya területén [7689.2] egy mélyedésben, nedves kőzettörmeléken 7 tövét (VIRóK et al. 2004). Jelen közleményben a faj második hazai, ember által létrehozott (synanthrop) termőhelyen történt megtelepedéséről számolunk be.

\section{Anyag és módszer}

A csermelyciprus megtalálása egy 2016. június 26-án tett terepbejárás során történt. Az előfordulást fényképpel és a Debreceni Egyetem TTK Növénytani Tanszék Soó Rezső herbáriumában (DE) elhelyezett példánnyal dokumentáltuk. A növény közvetlen közeléből, négy pontból, 20-30 cm mélységből talajmintát gyűjtöttük, elemzését a Debreceni Egyetem Agrártudományi Központ Karcagi Kutatóintézet akkreditált laboratóriuma végezte. A közlemény KIRÁLY (2009) nevezéktanát követi.

\section{Eredmények és értékelésük}

Egy Hejőpapi községhatárába tartozó, működő kavicsbánya (N $47.90647^{\circ}$ E $20.88167^{\circ}, 96$ m tszf., KEF: 8091.3) jelenleg művelés alól kivont felszínén a csermelyciprus egyetlen virágzó példányára bukkantunk, amelynek mintegy tucatnyi, 0,5-1,5 méter hosszúságú hajtása volt (1. ábra). A durva kavicsos, szerves anyagban igen szegény $(0,4 \%)$, bázikus kémhatású $\left(\mathrm{pH}_{\mathrm{KCl}} 7,7\right)$, alacsony $(<0,02 \mathrm{~m} / \mathrm{m} \%)$ sótartalmú, felvehető tápanyagokban szegény (nitrogén $<2,0 \mathrm{mg} / \mathrm{kg}$, foszfor $80 \mathrm{mg} / \mathrm{kg}$, kálium $25 \mathrm{mg} / \mathrm{kg}$ ) talajú termőhelyen a következő fajokat jegyeztük még fel: Apera spica-venti (L.) P. Beauv., Arenaria serpyllifolia L., Calamagrostis epigeios (L.) Roth, Lepidium densiflorum Schrad., Linaria genistifolia (L.) Mill., Viola arvensis Murray. A széllel terjedő magvakkal rendelkező, pionír fásszárúak közül továbbá a Salix purpurea L. és a Populus ×euramericana (Dode) Guinier magoncai és fiatal példányai telepedtek meg a termőhelyen. A megtalált példány 2016-ban történt magszórása esetleg elősegítheti a környéken újabb példányok megjelenését (Hejőpapi és Nyékládháza határában számos kavicsbánya is található), de a példány fennmaradása (és egy állomány kialakulásának lehetősége) teljes mértékben a termőhely művelésétől függ.

Ugyanakkor az előfordulás egyrészt jelzi a szél általi terjedés (anemochoria) hatékonyságát, hiszen a faj legközelebbi ismert lelőhelye (Rudabánya) légvonalban mintegy $60 \mathrm{~km}$ távolságra található (2. ábra), noha az sem kizárt, hogy a propagulum távolabbi

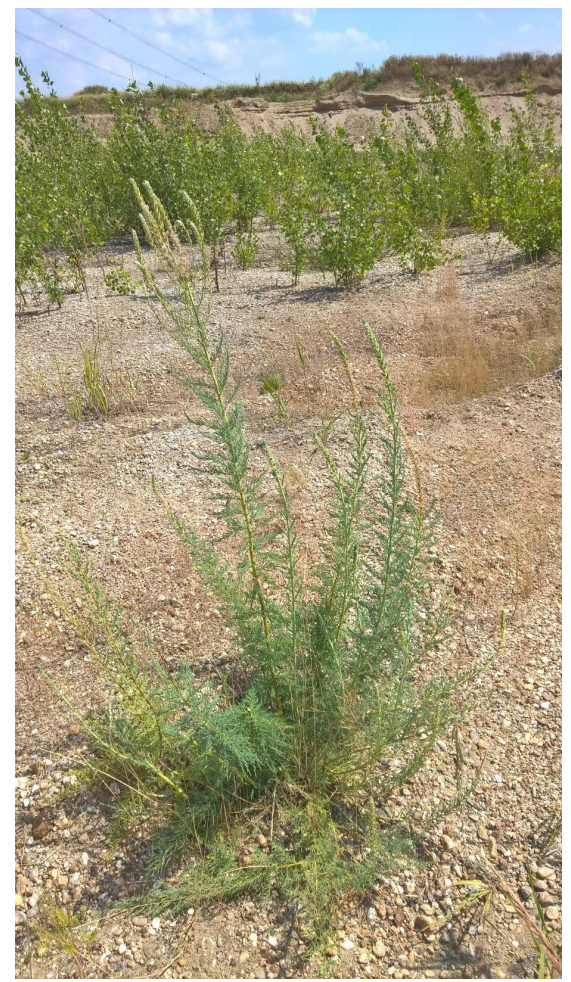

1. ábra. A csermelyciprus virágzó példánya Hejőpapi közelében, egy kavicsbányában

Fig. 1. Flowering individual of Myricaria germanica in a gravel pit near Hejőpapi (N Hungary) 
(akár határainkon kívül eső) állományból érkezett. Másfelől az eset felhívja a figyelmet arra, hogy egyes kavicsbányák (mindaddig amíg vannak nyílt, be nem növényesedett felületek) megfelelő termőhelyet jelenthetnek e hazánkban igen ritka előfordulású, veszélyeztetett fajnak, hasonlóan a Chamaenerion dodonaei-hez és a fokozottan védett Vicia biennis-hez (vö. TAKÁCS et al. 2013).

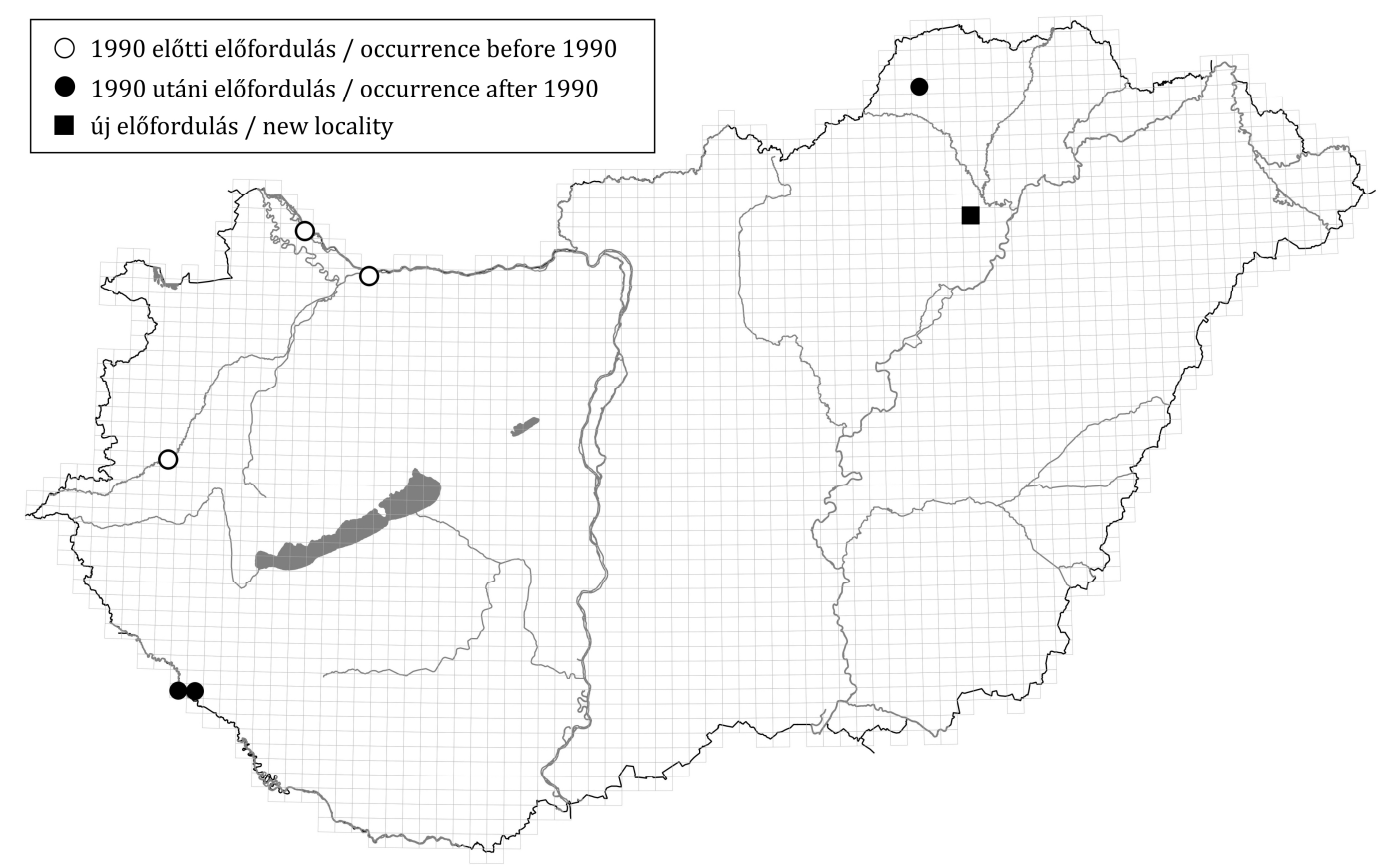

2. ábra. A csermelyciprus előfordulásai Magyarországon (BARTHA et al. 2015 alapján, módosítva) Fig. 2. Distribution of Myricaria germanica in Hungary (following BARTHA et al. 2015, modified)

\section{Köszönetnyilvánítás}

Köszönjük Krébesz Róbertnek a terepmunkában való részvételt, Takács Attilának a térkép elkészítésében való közreműködését, valamint Bartha Dénesnek és Virók Viktornak gyors és alapos lektori munkájukat. A munka az OTKA K108992 pályázat és a Magyar Köztársaság köztársasági ösztöndíjának támogatásával valósult meg.

\section{Irodalom}

BARINA Z. (2008): Adatok a Dunántúli-középhegység és környéke flórájához. - Flora Pannonica 6: 3-23. Bartha D., Király G., Schmidt D., Tiborcz V., Barina Z., Csiky J., Jakab G., Lesku B., Schmotzer A., Vidéki R., Vojткó A. \& Zólyomi Sz. (szerk.) (2015): Magyarország edényes növényfajainak elterjedési atlasza. [Distribution atlas of vascular plants of Hungary.] - Nyugat-magyarországi Egyetem Kiadó, Sopron, $329 \mathrm{pp}$.

Boros Á. (1954): Florisztikai közlemények IV. - Botanikai Közlemények 45: 247-250.

FENYŐSI L. \& HoRVÁTH Z. (1995): A csermelyciprusról. - Erdészeti Lapok 130: 350.

Goмвосz E. (1906): Sopron vármegye növényföldrajza és flórája. - Mathematikai és Természettudományi Közlemények 28: 401-577.

ILLYÉS Z. \& TóTH E. (2006): Új őszi füzértekercs (Spiranthes spiralis (L.) Chevall) előfordulás a Velenceihegységben. - Kitaibelia 10[2005]: 200. 
KIRÁLY G. (szerk.) (2007): Vörös Lista. A magyarországi edényes flóra veszélyeztetett fajai. [Red list of the vascular flora of Hungary.] - Saját kiadás, Sopron, 73 pp.

KIRÁLY G. (szerk.) (2009): Új magyar füvészkönyv. Magyarország hajtásos növényei. Határozókulcsok. Aggteleki Nemzeti Park Igazgatóság, Jósvafő, 616 pp.

KIRÁLY G. \& KIRÁLY A. (1998): Adatok Magyarország flórájának és vegetációjának ismeretéhez. Kitaibelia 3: 113-119.

KoRDA M. (2010): Csermelyciprus - Myricaria germanica (L.) Desv. In: BARTHA D. (szerk.): Magyarország ritka fa- és cserjefajai II. - Tilia 15: 139-148.

KovÁcs J. A. (1999): Adatok a Déli-Bakony flórájának ismeretéhez 1. - Kanitzia 7: 117-128.

Kun A. (1998): Sziklai növénytársulások az Érd-Tétényi-fennsíkon. - Kitaibelia 3: 65-70.

MATUS G. \& BARINA Z. (1998): Néhány újabb adat a Gerecse és környéke flórájához. - Kitaibelia 3: 281-286.

MATUS G. (1993): Néhány új florisztikai adat a Gerecséből. - Botanikai Közlemények 80: 41-45.

MÉszÁRos A. \& Simon P. (2009): Adatok Veszprém megye flórájához I. - Kitaibelia 14: 69-85.

Molnár V. A., MolnÁr A., VidéKi R. \& PFEIFFer N. (2000): Néhány adat Magyarország flórájának ismeretéhez. - Kitaibelia 5: 297-303.

MoLnÁR V. A. (2003): Növényritkaságok a Kárpát-medencében. - DE TTK Növénytani Tanszék \& WinterFair Kft., Debrecen \& Szeged, 232 pp.

NÉMETH F. (1979): Neue floristische Angaben über Ungarn. - Studia Botanica Hungarica 13: 75-77.

RanĐelović D., Gajić G., Mutić J., Pavlović P., Mihailović N. \& Jovanović S. (2016): Ecological potential of Epilobium dodonaei Vill. for restoration of metalliferous mine wastes. - Ecological Engineering 95: 800-810.

RehKlau W. (2003): Myricaria germanica (L.) Desv. 1825. - In: SchutT P., WeIsGerber H., Schuck H.J., LANG U.M. \& Roloff A. (Hrsg.), Enzyklopädie der Holzgewächse. Handbuch und Atlas der Dendrologie. ECOMED Verlagsgesellschaft, Landsberg, Band III/2/34., pp. 1-6.

STÖCKLIN J. (1992): Differences in the location of subcotyledonary buds among Epilobium angustifolium L., E. dodonaei Vill. and E. fleischeri Hochst. (Onagraceae) and effects on architecture and population structure. - Botanical Journal of the Linnaean Society 108: 35-47.

STÖCKLIN J. \& FAVRE P. (1994): Effects of plant size and morphological constraints on variation in reproductive components in two related species of Epilobium. - Journal of Ecology 82: 735-746.

TAKÁCs A., SCHMOTZER A. \& SulYoK J. (2013): Florisztikai adatok a Sajó-Hernád-sík területéről. - Kitaibelia 18: 73-88.

ViróK V., FARKAS R., SZMORAD F. \& Boldoghné SzÚTS F. (2004): Florisztikai adatok Borsod-Abaúj-Zemplénmegye északi részéről. - Kitaibelia 9: 143-150.

VIRóK V., FARKAS R., GulYás G. \& SRAmkó G. (2011): Florisztikai adatok Borsod-Abaúj-Zemplén megye északi részéről III. - Kitaibelia 15[2010]: 73-84.

VoJTKó A. (2008): Florisztikai adatok Észak-Magyarországról. - Kitaibelia 13: 55-61.

Beérkezett / received: 2016. 12. 28. • Elfogadva / accepted: 2017. 02. 10. 